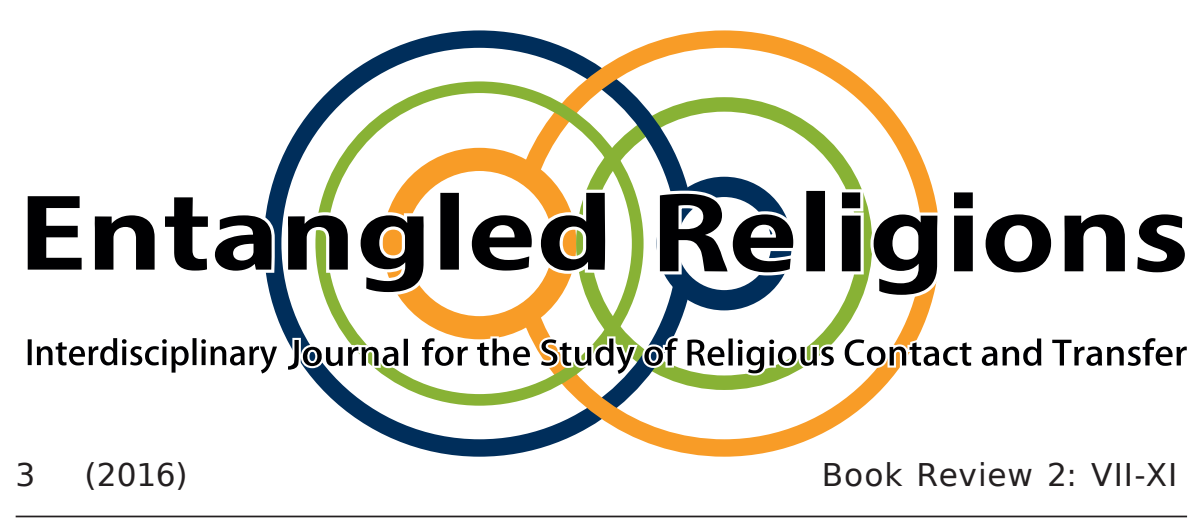

Religion, Migration, Settlement. Reflections on Post-1990 Immigration to Finland

Leiden/Boston: Brill, 2013. 159 pages, € 92,00/\$ 125.00, ISBN: 978-90-04-24846-5 (hardback), 978-90-04-25058-1 (e-book)

TUOMAS MARTIKAINEN

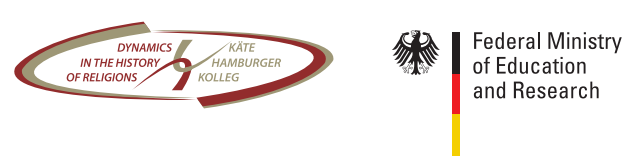




\section{Religion, Migration, Settlement. Reflections on Post-1990 Immigration to Finland}

Leiden/Boston: Brill, 2013. 159 pages, € 92,00/\$ 125.00, ISBN: 978-90-04-24846-5 (hardback), 978-90-04-25058-1 (e-book)

TUOMAS MARTIKAINEN

The Finnish sociologist of religion Tuomas Martikainen has published widely on issues related to immigrant religions in Finland and especially in his hometown of Turku. This little volume represents something like a collage of a number of these texts, gathering their insights together and putting them into context. Each of the ten short chapters in the book functions as a stand-alone piece, which can be understood independently of the rest of the book. Cross-references do occasionally exist, but they are not very numerous, and superfluous repetitions are much more common. Apart from a three-page preface, there are no apparent overarching passages, joining the different chapters into a coherent whole. This is especially noticeable in the lack of a general concluding chapter, which could wrap up the discussions in the ten chapters and structure them neatly.

This lack of clear-cut structure does not diminish the value of the individual chapters, however, which give a thorough theoretical grounding for the treatment of immigrant religion interspersed with very interesting case studies and examples from Finland. On the one hand, Finland might seem an untypical case, having become a country of immigration mainly after 1990. On the other hand, because of the small number of migrants involved, coupled with Finland being a modern, Western state, it might be 
a good place to test hypotheses, which may be less easily done among the more complex and larger immigrant communities of mainland West Europe. The lucidity of the Finnish case may help to rule out secondary factors from theoretical propositions developed based on more complex situations.

The first four chapters set the scene with theoretical and general insights. In the first chapter (pp. 1-17), Martikainen provides an overview of the state of research on general questions of migration, as well as statistical data on immigration to Finland and religions in Finland. The second chapter (pp. 18-33) covers theories of religion in modernity, based on James Spickard's six trajectories of theorising about modern religiosity: secularisation, fundamentalism, reorganisation, individualisation, religious market and globalisation. Moreover, the chapter includes a discussion of the debate on post-secular Europe, or the 'return' of religion to the political scene.

In chapter III (pp. 34-46), Martikainen provides a very good overview of various theories analysing the interplay between migration and religion. The focus is on integration and its two sides, namely the immigrants on the one hand and the host society on the other. This includes issues such as the reasons for migrating, which might include religion, and the ability to adapt to different cultural and social settings. The host societies differ widely regarding their openness and the opportunities granted newcomers. Also in this aspect, religion can play a major role, both negatively and positively.

Chapter IV (pp. 47-60) is primarily a critique of Martin Baumann's phase model of diaspora integration ${ }^{1}$ with regard to religious organisation. Martikainen does not reject Baumann's theory, but tries to refine it, mainly when it comes to new migrants who encounter an already existing

1 Baumann, Martin. 2002. “Migrant Settlement, Religion and Phases of Diaspora." Migration: $A$ European Journal of International Migration and Ethnic Relations 33/34/35:93-117. 
community, into which they can more easily integrate. This is especially the case with Christian migrants, who are very often overlooked, since they can visit existing Christian parishes and do not need to organise their religion from scratch. The same applies to Muslims arriving decades after the first Muslim immigrants. They can skip the first few phases of Baumann's model and join the already existing Muslim communities. Moreover, Martikainen criticises how Baumann seems to block out the importance of the local environment in which the diaspora tries to find its place. As he noted in the previous chapter, the host society also plays a very important role as enabler or disabler of religious pluralism.

The remaining chapters focus more on the Finnish case study, applying some of the theoretical insights of the previous chapters to Martikainen's field research. These chapters cover issues such as the glocality of immigrants religion, i.e. that local developments follow global logics, both in the migrant community (chapter $\mathrm{V}, \mathrm{pp} .61-72$ ) and in the host society (chapter VI, pp. 73-85). Chapter VII (pp. 86-98) covers the process by which the Finnish authorities come to terms with the religious plurality on the state territory. Using insights from Michel Foucault and Mitchell Dean, Martikainen shows how the authorities seek to govern and 'domesticate' foreign religions, primarily the Muslim presence in Finland.

Chapters VIII (pp. 99-109) and IX (pp. 110-125) cover the concrete organisational development and surrounding policy measures and discourses in the case of Orthodox and Muslim immigrants, whereas the last chapter (pp. 126-139) opens up the discussion of immigrant generations and their impact on religious socialisation and organisation. The end of the book comes as a surprise after this last chapter, which would have benefitted from a more thorough contextualisation with the rest of the book. 
Nevertheless, Martikainen's book is well suited to provide an overview and an introduction to the field of religion and migration. It covers most aspects of this field of research succinctly, providing examples from the field research in Finland, which might not be well known or immediately relevant, but which are easy to follow because of their limited complexity. Although Martikainen refers to several of Steven Vertovec's works throughout the volume, the latter's seminal article on "Religion and Diaspora"2, focussing on how religions change in a diaspora environment, is lacking from the reference list. Martikainen's focus on organisational and societal aspects of religion in migration contexts precludes the religious aspects enumerated in Vertovec's article. However, this religious dimension, in addition to a proper introduction and conclusion would have nicely complemented this otherwise highly informative book.

\section{SEBASTIAN RIMESTAD}

Erfurt, Germany

2 Vertovec, Steven. 2004. "Religion and Diaspora." In New Approaches to the Study of Religion, edited by Peter Antes, Armin W. Geertz, Randi R. Warne, 275-303. Berlin: de Gruyter. 